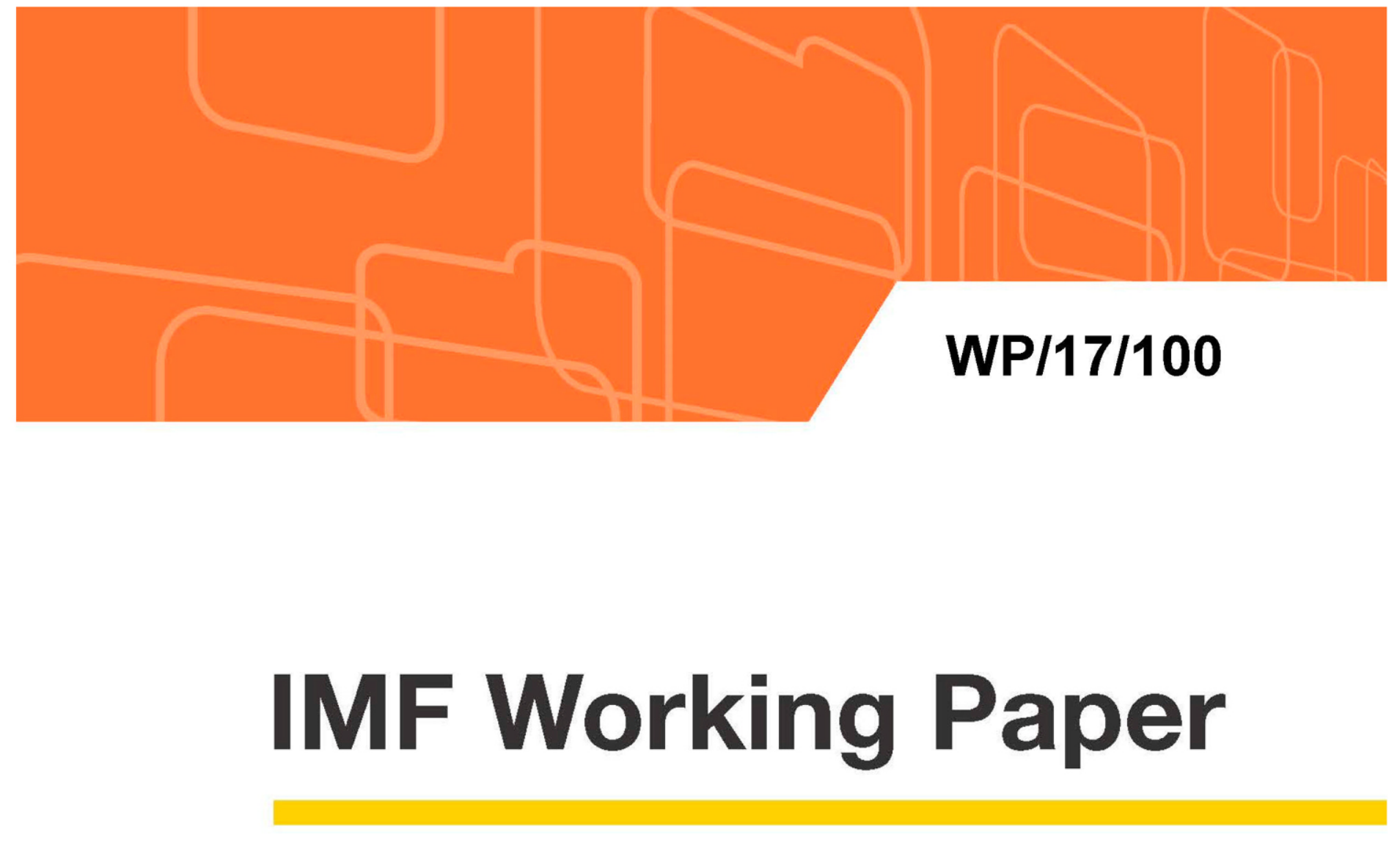

\title{
Revisiting the Potential Impact to the Rest of the Caribbean from Opening US-Cuba Tourism
}

by Sebastian Acevedo, Trevor Alleyne, and Rafael Romeu

IMF Working Papers describe research in progress by the author(s) and are published to elicit comments and to encourage debate. The views expressed in IMF Working Papers are those of the author(s) and do not necessarily represent the views of the IMF, its Executive Board, or IMF management.

$$
\text { I N T E R N A T I O N A L M O N E T A R Y F U N D }
$$




\section{WP/17/100}

\section{IMF Working Paper}

\section{Revisiting the Potential Impact to the Rest of the Caribbean from Opening US-Cuba Tourism}

by Sebastian Acevedo, Trevor Alleyne, and Rafael Romeu

IMF Working Papers describe research in progress by the author(s) and are published to elicit comments and to encourage debate. The views expressed in IMF Working Papers are those of the author(s) and do not necessarily represent the views of the IMF, its Executive Board, or IMF management.

$$
\text { I N T E R N A T | O N A L M O N E T A R Y F U N D }
$$




\title{
IMF Working Paper
}

Western Hemisphere Department

\section{Revisiting the Potential Impact to the Rest of the Caribbean from Opening US-Cuba Tourism}

\author{
Prepared by Sebastian Acevedo, Trevor Alleyne, and Rafael Romeu* \\ Authorized for distribution by Trevor Alleyne
}

March 2017

\section{IMF Working Papers describe research in progress by the author(s) and are published to} elicit comments and to encourage debate. The views expressed in IMF Working Papers are those of the author(s) and do not necessarily represent the views of the IMF, its Executive Board, or IMF management.

\begin{abstract}
The Cuban revolution and the subsequent US embargo on Cuba helped shape the tourism sector in the Caribbean, facilitating the birth and growth of alternative destinations. Therefore, the apprehension of the Caribbean tourism industry towards a change in US travel policy to Cuba is understandable, but likely unwarranted. The history of tourism in the region has shown that it is possible for all destinations to grow despite large changes in market shares. Our estimations show that liberalizing US-Cuba tourism could result in US arrivals to Cuba of between 3 and 5.6 million, most of it coming from new tourists to the region. We also identify the destinations most at risk of changes in US-Cuba relations.
\end{abstract}

JEL Classification Numbers: F13, F14, F15, Z30.

Keywords: Tourism, Cuba, Caribbean, Trade, Gravity model.

Author's E-Mail Address: sacevedomejia@imf.org, talleyne@imf.org, rromeu@devtechsys.com

\footnotetext{
* We thank Hanlei Yun for excellent research assistance.
} 


\section{Table of Contents}

ABSTRACT 2 2

I. INTRODUCTION __ $\underline{4}$

II. STYLIZED FACTS AND LONG TERM TRENDS IN CARIBBEAN'S TOURISM __ $\underline{\underline{5}}$

III. THE DATA AND THE GRAVITY MODEL OF TOURISM $\_1 \underline{10}$

A. The Gravity Model __ 10

B. The Data 111

IV. MEASURING THE IMPACT OF US-CUBA TOURISM ON THE REST OF THE CARIBBEAN

A. Estimating US-Cuba tourism flows

V. CONCLUSIONS AND POLICY IMPLICATIONS 16

VI. REFERENCES $\underline{18}$

VII. APPENDIX 19

\section{FIGURES}

Caribbean Tourist Arrivals, 1995-2014

Evolution of the Caribbean Tourism Market, 1995-2014

Canadian Tourists by Destination, 1995-2014

Caribbean Tourist Arrivals by Source, 2014

Caribbean Change in Share of Tourism Sources, 2000-2014

TABLES

1. Gravity Estimations

2. Actual vs. Predicted Arrivals 


\section{INTRODUCTION}

The growth of Caribbean tourism outside Cuba is partly a post-Cuban revolution phenomenon. After the Cuban revolution suceeded in taking power in 1959 and started nationalizing US assets in Cuba, the US imposed the economic embargo on the island in 1960 and imposed travel restrictions to the island in 1963. This closed US tourism to one of the prefered Caribbean destinations of US travelers. In 1953, the last year of tourism statistics in Cuba before the revolution ${ }^{1}$, Cuba received almost half of all tourist arrivals to the Caribbean; however, by 1980 Cuba had less than 3 percent of the market compared to the same set of countries. ${ }^{2}$

In the case of The Bahamas despite a long history of tourism promotion that started with the Tourism Encouragement Act of 1851, it was the US embargo on Cuba that provided "the main stimulus to the tourism industry" with much of the US tourists switching to The Bahamas (The Bahamas Ministry of Tourism, 2016). Tourist arrivals to The Bahamas went from 142,689 in 1954 to over a million in 1968. It is also not surprising that in 1967 the Mexican government recognizing the importance of tourism in the economy started to look for the ideal location to develop the industry, choosing Cancun among five other locations to be developed as a tourism destination (Council for the Promotion of Mexico's Tourism, 2016).

Since the US and Cuban governments announced the normalization of relations on December 2014, there has been a concern among Caribbean countries that a possible opening of US tourism to Cuba will spell trouble for the rest of the region. Since December 2014, the US relaxed travel restrictions to Cuba by allowing travel without prior authorization for 12 categories (e.g. family, journalism, professional research and meetings, education, humanitarian work, etc.), while still banning tourism flows. This resulted in a record year for Cuba's tourism sector in 2015, with growth in tourist arrivals of 17.4 percent (including growth of 21.8 percent in the "other" category where the US is grouped). ${ }^{3}$ Despite the rapid increase in arrivals to Cuba, the rest of the region fared quite well with an average growth of 6 percent from all tourism sources, and 6.6 percent growth in US tourist arrivals. So at least for now the region has been able to weather the slow increase in competition.

Recent work by Acevedo et al (2016) shows that countries in the region should not fear the loss of US flights once the US allows tourism to Cuba. Their results indicate that changes in US-Cuba flights (there were some 4,000 flights between the US and Cuba in 2014) do not

\footnotetext{
${ }^{1}$ The Cuban revolution started in July 1953, and the rebel forces seized control in January 1959.

${ }^{2}$ In 1953 only seven Caribbean countries reported tourist arrivals to the World Tourism Organization (WTO). Those countries were: The Bahamas, Barbados, Cuba, Dominican Republic, Haiti, Puerto Rico, and Trinidad and Tobago. In 1953 tourist arrivals to the Caribbean were 649,911 but by 1980 arrivals to the seven countries above had reached 4 million.

${ }^{3}$ Cuba's office of statistics (ONEI for its acronym in Spanish) does not report a separate line for US visitors, but the "other" category is a large residual after reporting the 17 largest source markets, and its believed to be mostly US visitors.
} 
have a negative impact on the availability of US flights to other Caribbean destinations. Their analysis leads them to conclude that the provision of airlift to the region is not a zero-sum game, where one destination's gain is another one's loss, and hence an orderly and gradual US-Cuba opening up should not affect the vital airlift services on which all Caribbean destinations depend for their tourism exports.

This paper follows the work of Romeu (2014, and 2008) to estimate the potential impact on tourism flows in the Caribbean following a full liberalization of travel between the US and Cuba. In these papers, a gravity trade model is used to analyze Caribbean tourism, with results indicating that opening US-Cuba tourism will result in an increase in US tourists to Cuba in the range of 3 to 3.5 million, andabout 1.5 million non-US tourists leaving Cuba for other destinations in the region. This paper follows the same methodology and an updated dataset, which includes the global financial crisis and the subsequent recovery, to estimate the impact of a change in US travel policy towards Cuba. The paper also includes Miami as a Caribbean tourist destination that might be affected by the normalization of US-Cuba relations.

The experience in 2015 and the work of Romeu (2014) and Acevedo et al (2016) suggest that while the Caribbean needs to prepare for more competition from Cuba, and tourism market shares for other Caribbean countries will be affected, the normalization of US-Cuba relations will not necessarily cause great disruption to the industry. This will be explored more throroughly in the rest of the paper, which is organized as follows. Section II presents some stylized facts about tourism flows to the Caribbean; Section III briefly discusses the model and the data; Section IV presents and discusses the main results; and Section V concludes.

\section{Stylized Facts and Long Term Trends in Caribbean's TourisM ${ }^{4}$}

Tourism flows in the Caribbean over the last 20 years show encouraging signs that opening US-Cuba tourism while increasing competition, will not necessarily disrupt US tourism flows to the rest of the region. First, it is important to note that over the last two decades, the tourism sector has grown throughout the Caribbean from 12 million arrivals in 1995 to 26 million in 2014. The notable exception is The Bahamas, where tourist arrivals have remained mostly flat since the mid-1990s. This regional expansion has taken place despite the very rapid growth experienced by the larger destinations over this period (Figure 1). Cuba's tourist arrivals grew at an average annual rate of 7.6 percent, Cancun's grew at 7.5 percent, and the Dominican Republic's grew at 5.7 percent, with the region as a whole growing at 4 percent per year.

\footnotetext{
${ }^{4}$ The analysis in the paper is limited to stay-over tourist arrivals and does not include the cruise sector, which is an important source of tourism receipts for some Caribbean countries, and is also going to face increased competition from Cuba.
} 
Figure 1. Caribbean Tourist Arrivals, 1995-2014
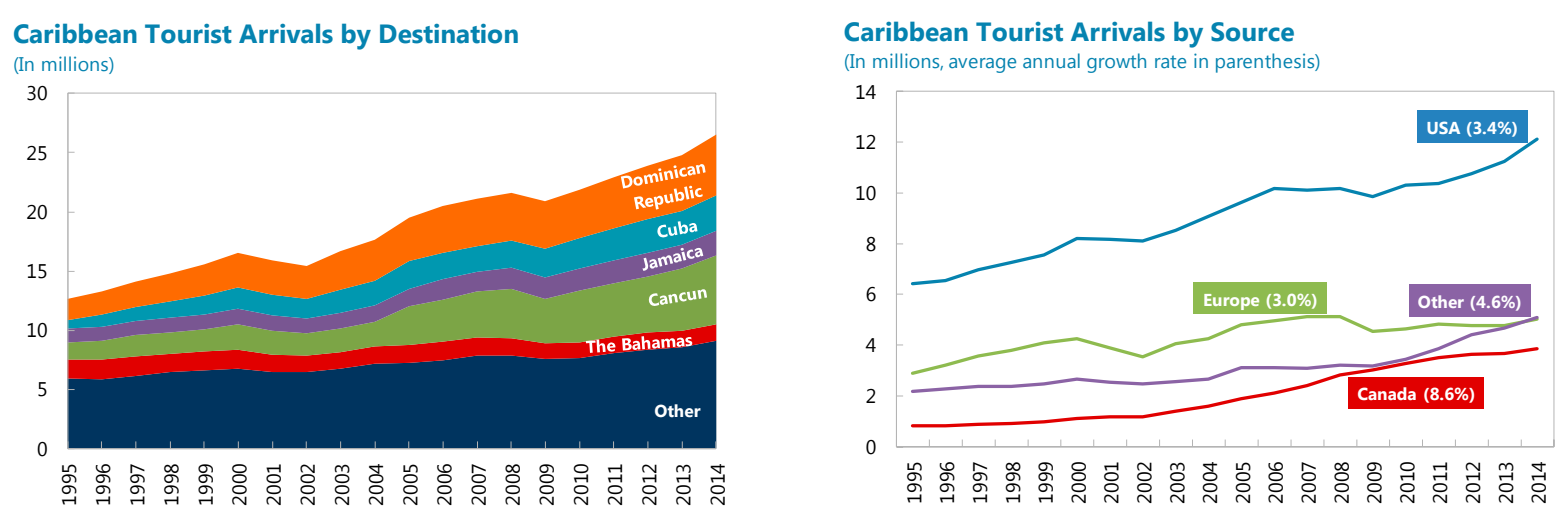

Sources: СTO; and Authors' calculations.

Note: In the case of destinations "Other" includes: Anguilla, Antigua and Barbuda, Aruba, Barbados, Belize, Bermuda, British Virgin Islands, Cayman Islands, Curaçao, Dominica, Grenada, Guyana, Haiti, Martinique, Montserrat, Puerto Rico, St. Lucia, St. Kitts and Nevis, St. Maarten, St. Vincent and the Grenadines, Suriname, Turks and Caicos, and US Virgin Islands. In the case of sources "Other" includes the rest of the world.

The Canadian market is of particular interest, because it has been the fastest growing tourism source in the Caribbean with an average annual growth rate of 8.6 percent (Figure 1). This has resulted in Canada's share of tourists more than doubling, and has reduced somewhat the region's dependence on the US tourism market (Figure 2, top panel). Canada's case is also interesting because Cuba has become Canada's main tourism destination in the Caribbean (Figure 2, middle panel). While "other" destinations, as a group, were the main recipients of Canadian tourist in 1995, by 2014 Canadian tourists were traveling more to Cuba, Cancun and the Dominican Republic. ${ }^{5}$ During this period Canada also replaced Europe as the main source of tourists in Cuba (Figure 2, bottom panel).

Despite the rapid growth of the tourism sector in Cuba thanks to the Canadian market, and to the impressive increase in the number of Canadian's vacationing in Cuba (11.7 percent annual growth between 1995 and 2014), the rest of the region has also benefited greatly from Canada's tourism expansion. While the share of Canadian tourists visiting "other" destinations in the Caribbean shrank by more than half in the past 20 years, the number of Canadian visitors to the "other" destinations still grew by 7.7 percent per year to 1.7 million (Figure 3). And for most countries in the Caribbean, Canada was the fastest growing market of tourism exports.

\footnotetext{
5 "Other" includes: Anguilla, Antigua and Barbuda, Aruba, Barbados, Belize, Bermuda, British Virgin Islands, Cayman Islands, Curaçao, Dominica, Grenada, Guyana, Haiti, Martinique, Montserrat, Puerto Rico, St. Lucia, St. Kitts and Nevis, St. Maarten, St. Vincent and the Grenadines, Suriname, Turks and Caicos, and US Virgin Islands.
} 
Figure 2. Evolution of the Caribbean Tourism Market, 1995-2014

Canada has been the fastest growing market in the Caribbean over the last 20 years, and as a result its share of the tourism market has more than doubled.

Caribbean Tourist Arrivals by Source
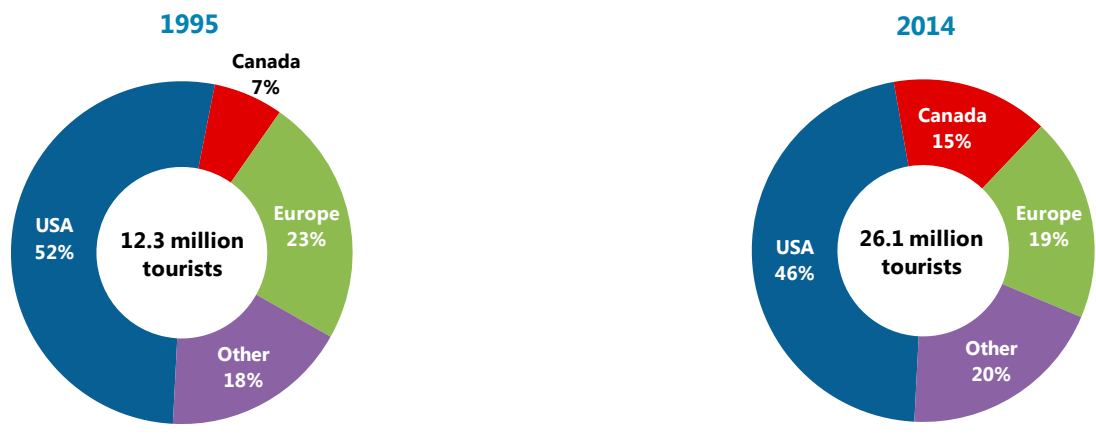

Canadian tourists have concentrated in Cuba, Cancun, and the Dominican Republic.

Canadian Tourists by Destination

1995

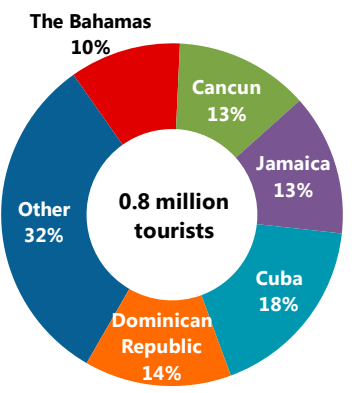

2014

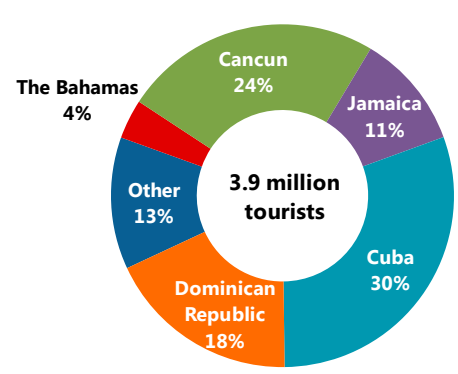

And, Cuba's tourism industry has concentrated in the Canadian market

Cuban Tourist Arrivals by Source

1995

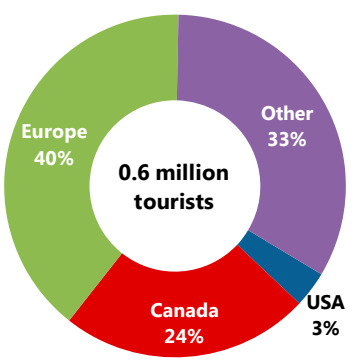

2014

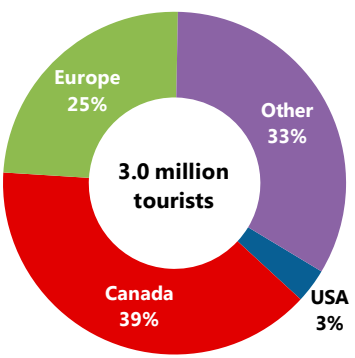

Sources: CTO; WTO; and authors' calculations

Note: In the case of destinations "Other" includes: Anguilla, Antigua and Barbuda, Aruba, Barbados, Belize, Bermuda, British Virgin Islands, Cayman Islands, Curaçao, Dominica, Grenada, Guyana, Haiti, Martinique, Montserrat, Puerto Rico, St. Lucia, St. Kitts and Nevis, St. Maarten, St. Vincent and the Grenadines, Suriname, Turks and Caicos, and US Virgin Islands. In the case of sources "Other" includes the rest of the world. 
Figure 3. Canadian Tourists by Destination, 1995-2014

(In million, average annual growth rate in parenthesis)

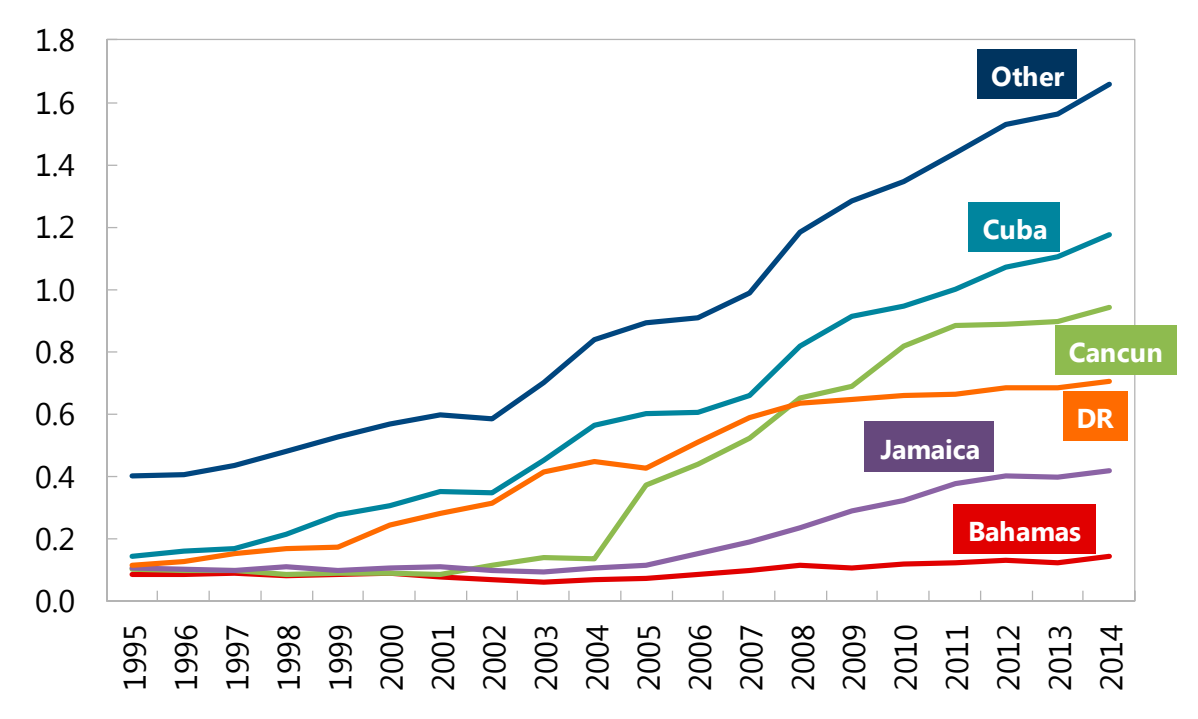

Sources: СТО; and authors' calculations.

Note: "Other" includes: Anguilla, Antigua and Barbuda, Aruba, Barbados, Belize, Bermuda, British Virgin Islands, Cayman Islands, Curaçao, Dominica, Grenada, Guyana, Haiti, Martinique, Montserrat, Puerto Rico, St. Lucia, St. Kitts and Nevis, St. Maarten, St. Vincent and the Grenadines, Suriname, Turks and Caicos, and US Virgin Islands.

The tourism flows from Canada to Cuba and the rest of the Caribbean strongly suggest that it is feasible for a tourism source market to have a rapid and sustained expansion in tourist arrivals to Cuba while at the same time growing and benefiting all the other countries in the region. This reflects the strong income elasticity of demand for tourism in the Caribbean, which overpowers price effects, as shown in Laframboise et al (2014). Although there is no guarantee that this will also be the case once the US government allows tourism into Cuba, there is no evidence to suggest that a quick expansion of US-Cuba tourism cannot coexist with a continued growth of US tourism to the rest of the region.

That said, some Caribbean destinations are more at risk of experiencing disruptions in their tourism sectors if a change in US policy allows unrestricted tourism travel to Cuba, and increases competition for US tourists. Figure 4, shows the countries whose tourism source is predominantly from the US (i.e. more than 50 percent). All the countries to the left of the white line depend heavily on US tourists, with the US Virgin Islands, Puerto Rico, Turks and Caicos, The Bahamas, Cayman Islands, and Bermuda receiving more than 70 percent of their tourists from the US. On the right side of the white line, the tourism destinations are more diversified away from the US, and, hence, if the number of US tourist visiting them were to decline, the shock would be smaller, and it would likely be easier for them to attract visitors from other countries to compensate for the decline in US visitors. 
Figure 4. Caribbean Tourist Arrivals by Source, 2014

(In percent of total)

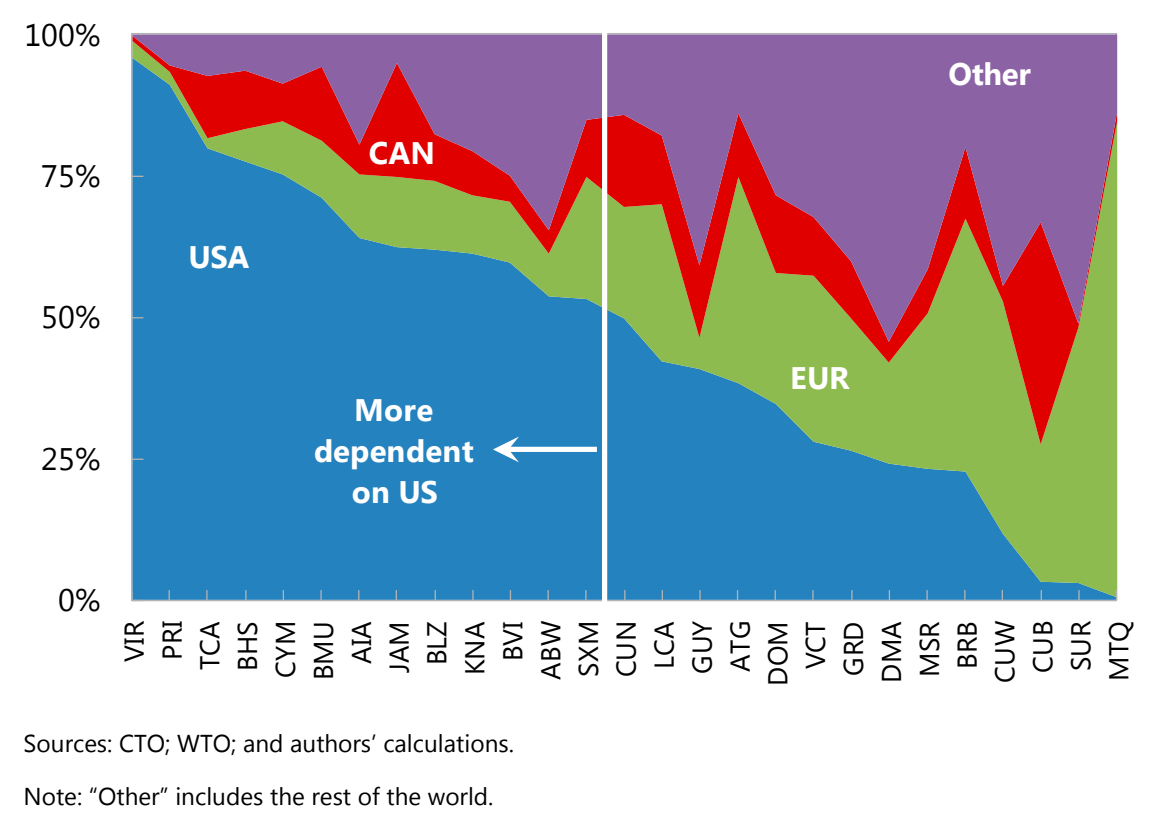

But it is not only how much dependency on US tourists a country currently has, it also matters how much the country's tourism strategy has concentrated recently in targeting the US market. To study this, we calculated the change in the share of tourists from all source markets, which is presented in Figure 5. All the countries to the left of the black bar have become more dependent on the US tourism market since the year 2000, while the countries to the right have diversified away from the US. The countries on the right are therefore better prepared to seek tourists from countries other than the US if a US-Cuba opening up were to result in a decline of US tourists to the region. The countries to the left of the bar seem to have focused their efforts in attracting more US tourists, so they are less prepared to diversify their visitor sources.

Not surprisingly, there is some overlap between the "most at risk" countries identified in Figures 4 and 5. In that group, the US Virgin Islands, Puerto Rico, and Turks and Caicos standout as the most vulnerable to a potential disruption in US tourists' flows. It is important to note that while some countries that currently have more than 50 percent of their visitors coming from the US have been diversifying away from the US market (e.g. The Bahamas and Bermuda), other countries that have a relatively low US dependency (e.g. Dominican Republic and Antigua and Barbuda) have actually been targeting more US tourist in the last 15 years. 
Figure 5. Caribbean Change in Share of Tourism Sources, 2000-2014 (In percent)

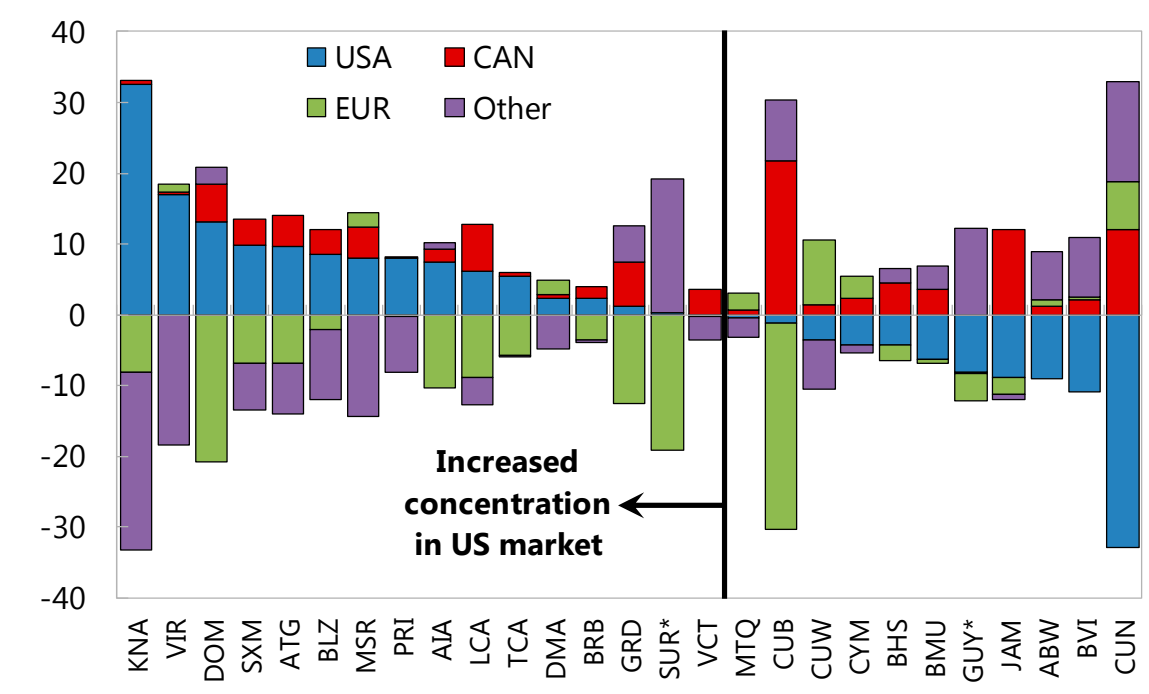

Sources: СТO; WTO; and authors' calculations.

Note: "Other" includes the rest of the world.

* For GUY the base year is 2001 and for SUR the base year is 2006.

\section{The Data And The Gravity Model OF TOURISM}

Since this paper is largely an update of the work of Romeu (2014), the following section will briefly present the main data sources and the intuition behind the gravity model of tourism in the Caribbean. Readers are referred to Romeu $(2014,2008)$ for a more detailed description of the methodology.

\section{A. The Gravity Model}

The gravity model methodology used by Romeu (2014) and closely followed in this paper is based on the work of Anderson and Van Wincoop (2003) and Baldwin and Taglioni (2006). The idea behind gravity models is that trade flows are determined by trade costs that are proxied by the physical distance between countries, and by other factors that affect trade links such as cultural and historical relations.

The estimated gravity model is as follows:

$$
\operatorname{lnT} A_{i j}=\alpha_{0}+\alpha_{1} I_{i t}+\alpha_{2} I_{j t}+\beta_{1} \text { Dist }_{i j}+\beta_{2} U S . C u b a_{t}+\boldsymbol{\delta} \boldsymbol{X}_{\boldsymbol{i j}}+\boldsymbol{\gamma} \boldsymbol{Z}_{\boldsymbol{i}}+e_{i j t}
$$

where the log of bilateral tourist arrivals to Caribbean destination $i$ from advanced economy $j$ is a function of destination-year $\left(I_{i t}\right)$ and source-year $\left(I_{j t}\right)$ indicators that capture non-systemic tourism determinants of destination and source countries (e.g., GDP); bilateral distance 
between the destination and source country capitals ${ }^{6}$; a dummy variable (US.Cubat) that captures the travel restrictions imposed by the US; a vector $\boldsymbol{X}_{i j}$ that includes other determinants of tourism flows such as whether the countries share a common language, have a common colonizer, have a colonial history, or are part of the same country (e.g. think of the US and Puerto Rico, and France and Guadalupe); and a $\boldsymbol{Z}_{\boldsymbol{i}}$ vector of variables that indicate if a destination country is part of different trade agreements (i.e. CARICOM, CAFTA, and the $\mathrm{CBI})^{7}$ that facilitate travel and investment, including in tourism facilities.

The model also includes a dummy variable for periods in which the US travel policy towards Cuba was more tightly enforced (1996-97 when the Helms-Burton Act increased sanctions, and 2004-08 when travel restrictions to Cuba were enforced more strongly). To account for non-linearity in distance we include a dummy variable for transatlantic tourists traveling from Europe to visit the Caribbean. The estimations also control for the effects of natural disasters, for the 2001 September 11 attacks that disrupted travel around the world, for the H1N1 outbreak in 2009, and for low-income country destinations which might have insufficient infrastructure capacity for a well-functioning tourism sector. The model also controls for measurement issues in Puerto Rico where its role as an air and maritime hub for the region and the potential misclassification of their diaspora as tourists might affect the tourism statistics. Finally, to get a sense of the impact that US tourists have on non-US arrivals we estimate this elasticity for each country.

\section{B. The Data}

The bilateral tourism data mainly come from the World Tourism Organization (WTO) statistical yearbooks, complemented with data from the Caribbean Tourism Organization (CTO). In the case of Miami, the tourism data come from the Greater Miami Convention and Visitors Bureau (GMCVB). The data on distance and cultural and historical links between countries are from CEPII's GeoDist database. The natural disasters data are from EM-DAT, where only disasters that affected more than 0.01 percent of the population are considered. The sample includes 40 destinations in the Caribbean, and 31 advanced economies (including Mexico) as source countries ${ }^{8}$, covering the period 1995-2014.

\section{Measuring THE IMPACT OF US-CUba TOURISM ON THE REST OF THE CARIBbEAN}

This section presents the results of the gravity model estimations in Table 1, and calculates the US tourist arrivals to Cuba in a counterfactual world in which there are no restrictions to travel between the two countries. The first column presents the main results while the other

\footnotetext{
${ }^{6}$ Distance is measured as the great-circle distance between countries capitals in miles.

${ }^{7}$ CARICOM is the Caribbean Community, CAFTA is the Central America Free Trade Agreement with the US, and the CBI is the Caribbean Basin Initiative that is an US initiative to promote economic development and export diversification.

${ }^{8}$ Tables 1A.a and 1A.b in the Appendix present a detailed list of the destination and source countries. The destinations include Central and South American countries that are usually not classified as part of the Caribbean, but are included in the sample because they are part of the Caribbean basin and offer tourism services that compete with the Caribbean. However, the analysis in the paper focuses on the Caribbean destinations.
} 
two columns present alternative specifications that serve as robustness checks. The results are broadly consistent with Romeu (2014) and have the expected signs. Distance as a proxy for trade costs is negative and statistically significant. However, there does not seem to be a non-linear effect to distance, given that the coefficient for Europe, while negative, is not statistically significant. Both the US-Cuba restrictions and the tightening of those restrictions are negative and significant, confirming that the US travel policy towards Cuba has had an important negative impact on the tourism sector in the island.

The variables that relate to cultural and historic ties (like common language, common colonizer, colonial ties, and same country) are, as expected, all positive and statistically significant. This suggest two things; i) if removing the US-Cuba travel restrictions diverts some US tourists away from other Caribbean destinations, the countries more likely to suffer are the ones that do not have these types of cultural/historical ties with the US; and ii) if as expected more US tourism in Cuba increases costs to visit the island and some non-US tourists are priced out and diverted to the rest of the Caribbean, the destinations more likely to benefit are the ones that share colonial and or cultural ties with Canadian and European source markets.

The effects of trade agreements (CAFTA, CARICOM, and CBI) seems to be mixed. While membership in CAFTA appears to benefit tourism flows, the CBI does not appear to have a statistically significant effect. On the other hand, membership of CARICOM seems to be negative for tourism, perhaps because this is an agreement among tourist destinations that does not include major tourism source countries like CAFTA with the US. ${ }^{9}$ The effect of the H1N1 epidemic is negative, as expected, but not statistically significant. The year a natural disaster strikes a destination tourist arrivals are negatively affected, highlighting one of the channels through which natural disasters affect growth in the Caribbean. Finally, low income countries tend to receive less tourists than the rest of the Caribbean, which is likely a reflection of lower quality infrastructure that makes them relatively less attractive to vacationers to the Caribbean.

The $\beta_{U S}$ parameters for each country show the sensitivity of tourist arrivals from non-US sources to an increase in US tourism flows. Most countries have a negative coefficient, although significant only in about half the destinations, suggesting that there is a substitution effect between US and non-US tourists. This could be the case if an increase in US tourism flows leads to price pressures and a reduction in demand from other source markets. This effect, could help offset some of the potential loss of US tourists once tourism flows between the US and Cuba are restored. However, the extent of the offset will not only depend on the substitution effect but also on the relative share of US to non-US tourist arrivals in each country.

\footnotetext{
${ }^{9}$ This result does not necessarily mean that being a member of CARICOM is bad for the tourism sector, only that the tourism sector among CARICOM members as a whole has underperformed with respect to nonmembers.
} 
Table 1. Gravity Estimations

\begin{tabular}{|c|c|c|c|}
\hline Variables & $\begin{array}{c}(1) \\
\operatorname{In} T A\end{array}$ & $\begin{array}{c}(2) \\
\operatorname{In} T A\end{array}$ & $\begin{array}{c}(3) \\
\ln T A\end{array}$ \\
\hline Distance & $-1.48^{\star \star \star}$ & $-1.55^{\star \star \star}$ & $-1.56^{\star \star \star}$ \\
\hline US-Cuba restrictions & $-3.41^{* * *}$ & $-3.61^{\star * *}$ & $-3.59^{* \star *}$ \\
\hline Tightening of restrictions & $-0.75^{\star * *}$ & $-0.73^{\star * *}$ & $-0.75^{\star \star *}$ \\
\hline Common language & $1.13^{* * *}$ & $1.08^{* * *}$ & $1.09^{* \star *}$ \\
\hline Common colonizer & $0.51^{* *}$ & $0.54^{* *}$ & $0.53^{* *}$ \\
\hline Colonial ties & $1.36^{* * *}$ & $1.40^{* \star *}$ & $1.41^{* * *}$ \\
\hline Same country & $1.19^{* *}$ & $1.15^{\star}$ & $1.11^{*}$ \\
\hline Europe & -0.16 & -0.17 & \\
\hline Puerto Rico & 0.78 & 1.04 & \\
\hline CAFTA & $0.40^{* *}$ & & $0.41^{* *}$ \\
\hline CARICOM & $-1.10^{*}$ & & \\
\hline $\mathrm{CBI}$ & 0.77 & & \\
\hline H1N1 epidemic & -0.12 & -0.18 & 0.10 \\
\hline Natural disasters & $-1.81^{*}$ & $-2.20^{\star \star \star}$ & $-1.92^{* * *}$ \\
\hline Low income country & $-1.18^{* * *}$ & $-1.27^{* * *}$ & $-1.37^{\star * *}$ \\
\hline 9/11 Attacks & $-7.43^{* * *}$ & $-7.53^{\star * *}$ & $-7.62^{* * *}$ \\
\hline \multicolumn{4}{|l|}{$\beta_{\text {US }}$} \\
\hline Anguilla & $-0.22^{\star * *}$ & $-0.22^{\star \star \star}$ & $-0.23^{* * *}$ \\
\hline Antigua and Barbuda & 0.04 & -0.03 & -0.04 \\
\hline Aruba & $-0.14^{\star \star \star}$ & $-0.18^{\star \star \star}$ & $-0.19^{* * *}$ \\
\hline Bahamas & -0.05 & $-0.12^{* \star *}$ & $-0.12^{\star \star *}$ \\
\hline Barbados & 0.00 & $-0.08^{*}$ & $-0.09^{* *}$ \\
\hline Belize & -0.06 & $-0.12^{\star \star}$ & $-0.13^{* * *}$ \\
\hline Bermuda & $-0.17^{* * *}$ & $-0.17^{* \star *}$ & $-0.18^{* * *}$ \\
\hline British Virgin Islands & $-0.13^{\star \star \star}$ & $-0.18^{\star \star \star}$ & $-0.19^{* * *}$ \\
\hline Cancun & $-0.08^{* *}$ & $-0.09^{* *}$ & $-0.08^{\star *}$ \\
\hline Cayman Islands & $-0.19^{* * *}$ & $-0.19^{* * *}$ & $-0.19^{* * *}$ \\
\hline Cuba & $-0.14^{* *}$ & $-0.15^{\star \star \star}$ & $-0.16^{\star * *}$ \\
\hline Curaçao & -0.09 & $-0.14^{* \star *}$ & $-0.15^{\star \star \star}$ \\
\hline Dominica & -0.06 & $-0.14^{* *}$ & $-0.16^{* *}$ \\
\hline Dominican Republic & 0.03 & -0.02 & -0.02 \\
\hline Grenada & -0.07 & $-0.16^{\star \star \star}$ & $-0.17^{* * *}$ \\
\hline Guadeloupe & $-0.17^{\star \star *}$ & $-0.17^{\star \star *}$ & $-0.18^{\star * *}$ \\
\hline Haiti & $-0.15^{\star \star \star}$ & $-0.20^{* \star *}$ & $-0.20^{* \star *}$ \\
\hline Jamaica & -0.03 & $-0.10^{\star * *}$ & $-0.11^{\star \star *}$ \\
\hline Martinique & 0.02 & 0.02 & 0.01 \\
\hline Miami & 0.02 & 0.02 & 0.01 \\
\hline Montserrat & $-0.20^{\star *}$ & $-0.30^{\star * *}$ & $-0.32^{* * *}$ \\
\hline Puerto Rico & -0.11 & -0.09 & $-0.13^{\star * *}$ \\
\hline Saba & -0.11 & $-0.21^{\star * *}$ & $-0.22^{* * *}$ \\
\hline Sint Maarten & -0.07 & $-0.13^{* * *}$ & $-0.13^{* * *}$ \\
\hline St. Eustatius & $-0.27^{\star \star \star}$ & $-0.35^{\star \star \star}$ & $-0.35^{\star * *}$ \\
\hline St. Kitts and Nevis & $-0.17^{* *}$ & $-0.24^{* * *}$ & $-0.26^{\star \star *}$ \\
\hline St. Lucia & -0.05 & $-0.14^{* * *}$ & $-0.15^{\star \star *}$ \\
\hline St. Vincent and the Grenadines & -0.07 & $-0.16^{\star * *}$ & $-0.17^{* * *}$ \\
\hline Trinidad and Tobago & $-0.16^{* *}$ & $-0.25^{\star * *}$ & $-0.26^{* * *}$ \\
\hline Turks and Caicos & $-0.30^{\star * *}$ & $-0.31^{* * *}$ & $-0.32^{* * *}$ \\
\hline US Virgin Islands & $-0.24^{\star * *}$ & $-0.25^{\star \star *}$ & $-0.26^{\star \star *}$ \\
\hline Observations & 9,520 & 9,520 & 9,520 \\
\hline $\mathrm{R}^{2}$ & 0.92 & 0.92 & 0.92 \\
\hline Adjusted $\mathrm{R}^{2}$ & 0.90 & 0.90 & 0.90 \\
\hline
\end{tabular}




\section{A. Estimating US-Cuba tourism flows}

To estimate the potential gain in US tourist arrivals to Cuba we calculate a counterfactual scenario using the estimations in Table 1 . We set both of the variables measuring the restrictions to zero while at the same time setting the $\mathrm{CBI}$ variable for Cuba to one, that is we assume that the US includes Cuba as part of the CBI initiative. The results indicate that USCuba tourist arrivals could increase between 3 and 5.6 million depending on the model. ${ }^{10}$ These results are close to the ones presented in Romeu (2014) where the author estimates that US tourists visiting Cuba would increase between 3 and 3.5 million.

The models estimated above do not allow for a direct measure of trade diversion effects, that is, how many US tourists would leave the rest of the Caribbean for Cuba, and how many non-US visitors to Cuba would in turn decide to travel elsewhere in the Caribbean. However, comparing the actual tourist arrivals with the ones predicted by the gravity model we can infer which destinations would be more at risk and which ones are more likely to benefit from removing tourism restrictions between the US and Cuba. ${ }^{11}$ Interpreting the comparison of actual versus predicted arrivals in Table 2 must be done carefully. The first caveat is that only the US arrivals to Cuba are affected by the counterfactual (i.e. removing the restrictions), all the differences in the other bilateral tourism flows are determined by the fundamentals of the model (distance, cultural and historical links, etc.).

The other caveat is that there are two possible interpretations of the results. The first one is to interpret the finding that a destination has more tourist arrivals than what the model predicts (cells in red in Table 2) as a high performing destination; it is likely that these destinations have other positive attributes like great service quality or very competitive pricing of tourism services that are not captured by the model. This could explain why some of the largest destinations (e.g. Cancun, Dominican Republic, Jamaica) which tend to have business models that focus more on mass tourism with lower costs than smaller niche markets, receive more tourists than what the model suggests. An alternative interpretation could be that these destinations have been benefiting from the US-Cuba travel restrictions and are therefore more at risk of losing some US tourists once travel to Cuba is fully freed.

With those caveats in mind, the results in the three models show that overall tourism to the Caribbean would increase by opening up US-Cuba tourism. However, Table 2 suggests that part of Cuba's gains in US tourism would be at the expense of other destinations (the ones with red cells in the US column). But the models also suggest that some Canadian and European tourists that currently visit Cuba could decide to visit other countries in the region once the US tourists start to come into Cuba pushing prices up (countries with green cells in the Canada and UK columns). Interestingly, the models indicate that Miami could benefit from Canadian and UK visitors leaving Cuba as it is the closest Caribbean destination to both source countries and has close cultural and historical ties. One could argue that the US travel

\footnotetext{
${ }^{10}$ Model 1 predicts the highest gains (5.6 million), while model 2 predicts gains of 3.2 million, and model 3 predicts an increase in US tourists to Cuba of 3 million.

${ }^{11}$ An alternative would be to use some of the parameters estimated in the gravity model as assumptions of potential changes in tourism flows as was done in Romeu (2014).
} 
restrictions to Cuba have in some ways punished the Miami tourism industry by making Cuba artificially cheap for Canadian tourists which would have otherwise vacationed in Miami. Hence, a reversal of the US policy towards Cuba could potentially be a windfall to Miami.

Table 2. Actual vs. Predicted Arrivals

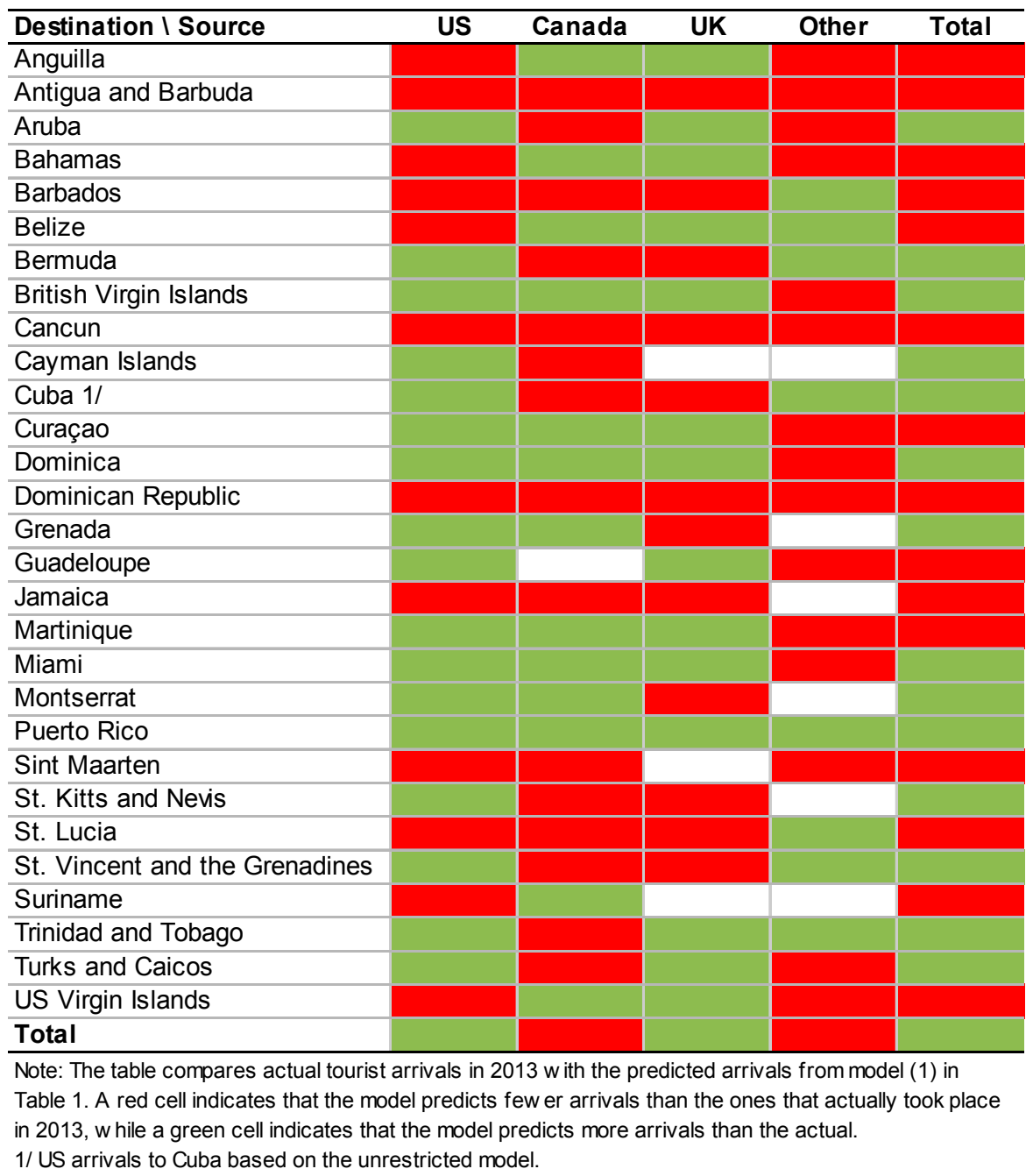

Although it is not possible to pinpoint exactly which destinations will face more challenges from a US change in policy towards Cuba, the analysis presented in here does suggest the most likely candidates. Figure 6 summarizes the information presented in the paper, identifying Anguilla, Belize, Saint Maarten, and the US Virgin Islands as the more vulnerable group. This does not mean that the other destinations are completely safe, or that this particular group will see declining US tourism flows, it only highlights the countries that would need to be more alert to changes in the US-Cuba relationship for possible spillovers. Furthermore, the analysis done here is a static one that holds income constant and studies the possible changes in market shares due to normalization of US-Cuba travel, but with moderate 
growth in advanced economies expected to continue, the tourism sector in the Caribbean as a whole is projected to continue growing over the long run.

\section{Figure 6. Most Vulnerable Destinations}

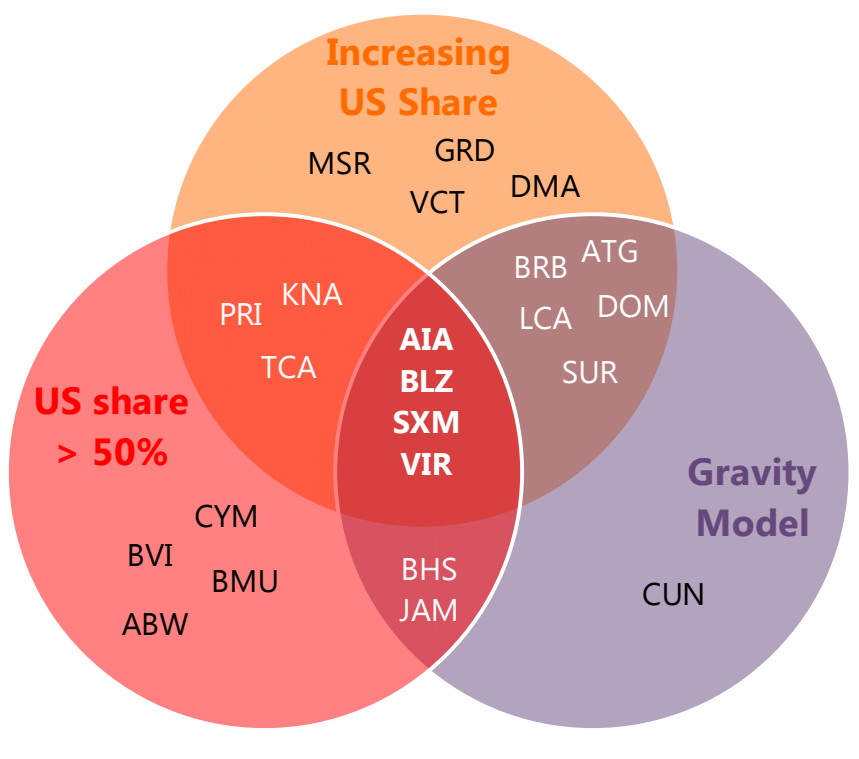

Sources: Authors' calculations.

Note: The share of US tourists larger than 50 percent is based on Figure 4, the increasing share of US tourist arrivals is based on Figure 5, and the gravity model is based on Table 2 (US column).

\section{CONCLUSIONS AND POLICY IMPLICATIONS}

The potential opening up of US-Cuba tourism has the Caribbean region concerned, and understandably so. After all, the US is the single largest tourism market for the Caribbean and, for most countries, the most important source of tourists. Nonetheless, the analysis presented in this paper suggests that this anxiety may be misplaced. Tourist arrivals have grown throughout the region (with the exception of The Bahamas) over the last 20 years, accommodating rapid expansion in some destinations (Cancun, Cuba, and the Dominican Republic). As such, there is no reason to suggest that the sector will not continue to expand in the future. While tourism shares have shifted with Cancun, Cuba, and the Dominican Republic becoming larger players in the region, the rest of destinations have still managed to grow their sectors at respectable rates, even as their market shares have declined.

Furthermore, Canadian tourists have been the fastest growing market in the region and in particular have become the most important market for Cuba. And still Canadian tourism has grown in all destinations at a very fast pace despite the fierce competition with Cuba. There is no reason to believe that free travel between the US and Cuba would be very different. There will be a period of adjustment and more intense competition, which, as in the past, the Caribbean destinations must confront with sensible policies. But the process is likely to be gradual, for example, Cuba will also need to adjust its economic policies to be able to scale up investment and improve the quality of its tourism services. This will allow time for other 
Caribbean destinations to adapt to the new equilibrium and tourism flows will continue to grow.

The gravity models show that completely removing the US travel restrictions to Cuba would significantly increase tourism flows, resulting in an increase in US tourist arrivals of between 3 and 5.6 million. However, this increase will not happen overnight, because: i) the US has been slowly removing restrictions and facilitating travel, and ii) even if there were a sudden and complete removal of travel restrictions, it would take some time for the tourism industry in the US and Cuba to adapt, and absorb more US visitors to Cuba.

The change in US policy is expected to benefit the region as a whole as the models indicate that aggregate tourism flows will grow. The increasing US tourism demand in Cuba will push prices up and result in a shift of some Canadian and European tourists, who would have otherwise visited Cuba, to travel to other Caribbean destinations. This will partly offset any potential loss of US tourists that some destinations might suffer in the adjustment phase to the new equilibrium.

There are some policy recommendations that will help Caribbean tourism destinations confront the increased competition from Cuba in the US market. Despite their generality, they are worthwhile in their own right. Our analysis shows that dependence on the US market is large, and while this dependence is understandable in terms of the proximity and size of the US market, a diversification strategy that targets other advanced economies and large emerging markets in Latin America would be beneficial. Improving the competitiveness of the tourism sector will be crucial, and improving quality and reducing costs will help countries compete with a low cost provider as Cuba. Finally, thinking of regional strategies to facilitate intra-regional travel would help bring the possibility of multi- destination vacations. This would help the rest of the Caribbean to benefit from the new tourists that will start visiting the region when the US opens up free travel to Cuba.

It is encouraging that the region is actively addressing some of this challenges. The tourism authorities and local hoteliers are proactively embarking on efforts to enhance their tourism product by tapping into new markets; developing new products; promoting investment; building new partnerships, and; developing human capital. In addition, the Caribbean Hotel and Tourism Association has been actively engaging the Cuban authorities to explore partnerships in promoting multi-destination initiatives. These various initiatives should mitigate the risk of decline in tourist arrivals from the US to the Caribbean 


\section{REFERENCES}

Acevedo, S., Han, L., Kim, M., and N. Laframboise, 2016, "Flying to Paradise: The Role of Airlift in the Caribbean Tourism Industry," IMF Working Paper WP/16/33, (Washington, DC: International Monetary Fund).

Anderson, J. and E. Van Wincoop, 2003, "Gravity with Gravitas: A Solution to the Border Puzzle," American Economic Review, 93, 170-92.

The Bahamas, Ministry of Tourism, 2016, "The History of the Ministry of Tourism," Available: http://www.tourismtoday.com/about-us/tourism-history

Baldwin, R., and D., Taglioni, 2006, "Gravity for Dummies and Dummies for Gravity Equations," NBER Working Paper No. w12516.

Centre d'Etudes Prospectives et d'Informations Internationales (CEPII), 2015, GeoDist Database, Available: http://www.cepii.fr/CEPII/en/welcome.asp

Council for the Promotion of Mexico's Tourism, 2016, "Cancun," Available: http://www.visitmexico.com/es/cancun

EM-DAT: The OFDA/CRED International Disaster Database. Université Catholique de Louvain -Brussels- Belgium, www.emdat.be.

Greater Miami Convention and Visitors Bureau, 2009-2013, Greater Miami and the Beaches: Visitor Industry Overview (Miami: Greater Miami Convention and Visitors Bureau).

Laframboise, N., Mwase, N., Park, J., and Y. Zhou, 2014, "Revisiting Tourism Flows to the Caribbean: What is Driving Arrivals?" IMF Working Paper WP/14/229, (Washington, DC: International Monetary Fund).

Oficina Nacional de Estadísticas e Información (ONEI), 2016, “Tourism: Arrivals of International Visitors, January December 2015” (in Spanish), Available: http://www.one.cu/publicaciones/06turismoycomercio/llegadadevisitantes/2015121leg adadevisitantes.pdf

Romeu, R., 2008, "Vacation Over: Implications for the Caribbean of Opening U.S.-Cuba Tourism,” IMF Working Paper WP/08/162, (Washington, DC: International Monetary Fund).

Romeu, R., 2014, “The Vacation Is Over: Implications for the Caribbean of Opening U.S.Cuba Tourism," Economía, 14(2), 1-24.

World Tourism Organization, 1950-2014, Yearbook of Tourism Statistics (Madrid: World Tourism Organization). 


\section{APPENDIX}

Table 1A. Sample of Destination and Source Countries

Table 1A.a. Sample of Destinations

\begin{tabular}{llrr}
\hline Destination & Code & Observations & Percent \\
\hline Anguilla & AIA & 119 & 1.3 \\
Antigua and Barbuda & ATG & 170 & 1.8 \\
Aruba & ABW & 229 & 2.4 \\
Bahamas & BHS & 366 & 3.8 \\
Barbados & BRB & 428 & 4.5 \\
Belize & BLZ & 151 & 1.6 \\
Bermuda & BMU & 157 & 1.6 \\
Bonaire & BQ1 & 34 & 0.4 \\
British Virgin Islands & BVI & 211 & 2.2 \\
Cancun & CUN & 364 & 3.8 \\
Cayman Islands & CYM & 326 & 3.4 \\
Colombia & COL & 395 & 4.1 \\
Costa Rica & CRI & 314 & 3.3 \\
Cuba & CUB & 483 & 5.1 \\
Curaçao & CUW & 252 & 2.6 \\
Dominica & DMA & 308 & 3.2 \\
Dominican Republic & DOM & 299 & 3.1 \\
Grenada & GRD & 395 & 4.1 \\
Guadeloupe & GLP & 114 & 1.2 \\
Guatemala & GTM & 449 & 4.7 \\
Guyana & GUY & 30 & 0.3 \\
Haiti & HTI & 57 & 0.6 \\
Jamaica & JAM & 377 & 4.0 \\
Martinique & MTQ & 112 & 1.2 \\
Miami & MIA & 101 & 1.1 \\
Montserrat & MSR & 112 & 1.2 \\
Nicaragua & NIC & 461 & 4.8 \\
Panama & PAN & 243 & 2.6 \\
Puerto Rico & PRI & 456 & 4.8 \\
Saba & BQ2 & 30 & 0.3 \\
Sint Maarten & SXM & 89 & 0.9 \\
St. Eustatius & BQ3 & 54 & 0.6 \\
St. Kitts and Nevis & KNA & 150 & 1.6 \\
St. Lucia & LCA & 197 & 2.1 \\
St. Vincent and the Grenadines & VCT & 223 & 2.3 \\
Suriname & SUR & 19 & 0.2 \\
Trinidad and Tobago & TTO & 381 & 4.0 \\
Turks and Caicos & 186 & 2.0 \\
US Virgin Islands & 305 & 3.2 \\
Venezuela & & 373 & 3.9 \\
Total & 100.0 \\
\hline & & \\
\hline
\end{tabular}

Table 1A.b. Sample of Sources

\begin{tabular}{|c|c|c|}
\hline Source & Observation & Percent \\
\hline Andorra & 135 & 1.4 \\
\hline Austria & 380 & 4.0 \\
\hline Belgium & 372 & 3.9 \\
\hline Canada & 707 & 7.4 \\
\hline Cyprus & 143 & 1.5 \\
\hline Denmark & 330 & 3.5 \\
\hline Faroe Islands & 29 & 0.3 \\
\hline Finland & 284 & 3.0 \\
\hline France & 517 & 5.4 \\
\hline Germany & 535 & 5.6 \\
\hline Gibraltar & 29 & 0.3 \\
\hline Greece & 276 & 2.9 \\
\hline Iceland & 162 & 1.7 \\
\hline Ireland & 251 & 2.6 \\
\hline Italy & 538 & 5.7 \\
\hline Luxembourg & 230 & 2.4 \\
\hline Malta & 177 & 1.9 \\
\hline Mexico & 353 & 3.7 \\
\hline Netherlands & 478 & 5.0 \\
\hline Norway & 340 & 3.6 \\
\hline Portugal & 308 & 3.2 \\
\hline San Marino & 122 & 1.3 \\
\hline Spain & 434 & 4.6 \\
\hline Sweden & 429 & 4.5 \\
\hline Switzerland & 486 & 5.1 \\
\hline Turkey & 202 & 2.1 \\
\hline United Kingdom & 561 & 5.9 \\
\hline United States of America & 712 & 7.5 \\
\hline Total & 9,520 & 100.0 \\
\hline
\end{tabular}

